
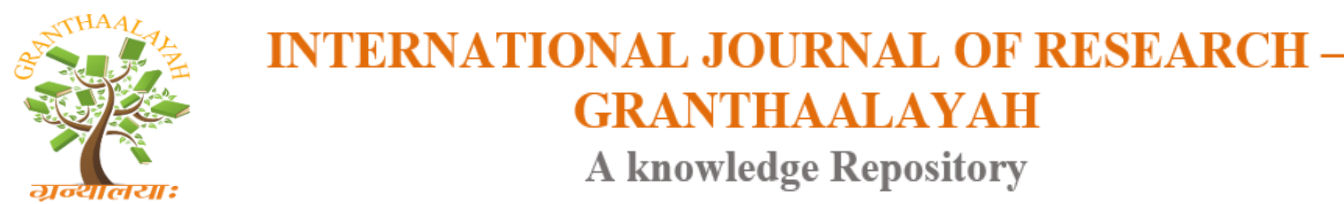

Science

\title{
VARIATIONS IN NUTRIENT AND PHYTOCHEMICAL CONSTITUENTS IN LEAF, STEM AND ROOT OF Garcinia Manni Oliv. DOMESTICATED IN TROPICAL SOIL
}

\author{
Etukudo Mbosowo M. ${ }^{* 1}$, Fubara Gift E. ${ }^{2}$ \\ ${ }^{* 1}$ Department of Biology, Federal University Otuoke, P.M.B 126, Yenagoa, Bayelsa State, \\ Nigeria \\ ${ }^{2}$ Department of Forestry and Environment, Rivers State University, Nkpolu-Oroworukwo, Port
} Harcourt

\begin{abstract}
Variations in nutrient and phytochemical constituents in leaf, stem and root of Garcinia manni (Oliv.) domesticated in tropical soil of Akwa Ibom State were assessed. Plant materials (leaf, stem and root) were collected from three (3) sampling locations in the study area. Elemental nutrient, proximate and phytochemical contents in the leaf, stem and root of $\mathrm{G}$. manni were determined using standard procedures. There were significant $(\mathrm{P}<0.05)$ variations in contents of nutrient elements, proximates and phytochemicals in leaf, stem and root of the test plant. The contents of anti-nutrients (cyanide, phytate, oxalate and glycoside) were relatively lower in stem than those of the leaf and root of the test plant. This study suggests that the test plant parts could be used as valuable material for the production of pharmaceutical drugs. In addition, the lower contents of anti-nutrients in the stem attest to its utilization as chewing stick.
\end{abstract}

Keywords: Variations; Nutrient; Phytochemical; Garcinia Manni; Tropical Soil.

Cite This Article: Etukudo Mbosowo M., and Fubara Gift E.. (2018). "VARIATIONS IN NUTRIENT AND PHYTOCHEMICAL CONSTITUENTS IN LEAF, STEM AND ROOT OF GARCINIA MANNI OLIV. DOMESTICATED IN TROPICAL SOIL.” International Journal of Research - Granthaalayah, 6(1), 400-407. 10.29121/granthaalayah.v6.i1.2018.1634.

\section{Introduction}

The role of plants as sources of medicinal compounds for the maintenance of human health cannot be over emphasized (Etukudo and Osim, 2018). Studies on the use of plant for natural therapies have increased due to their importance as valuable sources of natural products for maintaining human health (Abdillahi et al., 2010, Inbathamizh and Padmini, 2013). Similarly, the use of plant compounds for pharmaceutical purposes has gradually increased in some areas. Interestingly, more individuals from developed countries use traditional medicine, which has compounds derived from medicinal plants (Okeke and Nwachukwu, 2009, Garboni et al., 2009, Atangwho et al., 2009). Therefore, it becomes pertinent to investigate such plants to better 
understand their properties, safety and efficiency (Nascimento et al., 2000). Antimicrobial and antioxidant activities have been reported as crucial functions of phytochemicals such as terpenoids, flavonoids, alkaloids, polyphenols, tannins, saponins, pigments, enzymes and minerals have antimicrobial and antioxidant activity (Oboh and Masodje, 2009, Atangwho et al., 2009). One of the basic steps in the discovery of antimicrobial drugs is the antimicrobial screening of plant extracts and phytochemical analysis (Okwu and Ekeke, 2003, Selma et al., 2010). The test plant Garcinia manni is an important species in terms of its medicinal, nutritional and ecosystem benefits. It is because of the economic importance of non-timber forest products (NTFP) to the people that much interest and consideration have been given to studies in this area (Akande and Hayashi, 1998).

Garcinia manni Oliv. Belongs to the family Guttiferae (Clusiaceae), and is one of the commonly used plant species for maintenance of oral hygiene (Akande and Ajao, 2011). In Africa, it is usually employed in form of chewing stick, which has been recommended for oral hygiene by the World Health Organisation. Extracts from this species have been reported to exhibit antimicrobial potency against some microorganisms (Rotimi et al., 1988). The antimicrobial properties of plants have been investigated by a good number of researchers globally and a vast number of known plant species have been used for therapeutic treatments. This research was conducted to evaluate the variations in nutrient and phytochemical constituents in leaf, stem and root of Garcinia manni domesticated in tropical soil of Akwa Ibom State.

\section{Materials and Methods}

\subsection{Study Area}

Plant materials used for this research were obtained from Ukanafun Local Government Area in Akwa Ibom State, Nigeria. Ukanafun has coordinates of $4^{\circ} 54^{\prime} \mathrm{N}$ and $7^{\circ} 36^{\prime} \mathrm{E}$ Akwa Ibom State records a mean annual rainfall of about $2000 \mathrm{~mm}$ with an average annual minimum $\left(23^{\circ} \mathrm{C}\right)$ and maximum $\left(31.7^{\circ} \mathrm{C}\right)$ temperatures (Ayang, 2013, Wokocha and Nneke, 2011).

\subsection{Collection of Plant Samples}

Leaf, stem and root samples of G. manni were collected from three (3) sampling locations in Ukanafun Local Government Area.

\subsection{Analysis of Nutrient Element}

The plant samples (Leaf, stem and root) of the test plant were treated separately. Plant materials were dried after rinsing thoroughly with distilled water. The plant materials were crushed into powdered form followed by sieving through a $0.001 \mathrm{~mm}$ wire mesh to obtain a fine powdered form. The samples were placed in small bottles for analysis. Ammonium-vanadate-molybdate method was used to determine phosphorus content by spectrophotometry. Potassium was determined by frame photometer, while other elements were assayed by atomic absorption spectrophotometer (A.O. A.C, 1999, Hack, 2000). 


\subsection{Proximate Analysis}

Proximate values of the plant material (leaf, stem and root) were determined using standard procedure (A.O.A.C, 1999, Hack, 2000).

\subsection{Phytochemical Analysis}

The plant materials (leaf, stem and root) were analysed for the proportion of simple alkaloids, tannins, flavonoids, saponins, and glycosides, phytates, oxalates and cyanides using standard procedures [Bohn and Kocipai-Abyazan, 1994, Harborne, 1973, Obadoni and Ochuko, 2001, Pearson, 1976, Ikediobi et al., 1980, Olugboji, 1987, Oberlease, 1962].

\subsection{Statistical Analysis}

Standard errors of the mean values were calculated and were subjected to analyses of variance (ANOVA) at $0.05 \%$ probability level (Obi, 2002).

\section{Results and Discussions}

\subsection{Results}

The magnesium, potassium, phosphorus, nitrogen, zinc and copper contents in leaf of Garcinia manni were significantly $(\mathrm{P}<0.05)$ higher than those of the stem and root (Table I). The calcium, sodium and iron contents in root of $G$. manni were comparatively $(\mathrm{P}<0.05)$ higher than those of the leaf and stem (Table I). Although, the stem of the test plant did not record any highest value of nutrient element, its value of magnesium and copper were higher than those of the root (Table I).

The moisture content, crude protein and crude lipid were significantly $(\mathrm{P}<0.05)$ higher than those of the stem and root, while the dry matter and carbohydrate contents in stem of the test plant were comparatively higher than those of the leaf and root (Table 2). Similarly, the ash and crude fibre contents in root of G. manni were relatively higher than those of the leaf and stem (Table 2).

The alkaloid, tannin, saponnin, phytate and oxalate contents in leaf of G. manni were comparative $(\mathrm{P}<0.05)$ higher than those of stem and root, while the flavonoid, glycosides and cyanide contents in roots lower than those of the leaf and stem (Table 3). However, the stem recorded the lowest values of all phytochemicals analyzed in this study (Table 3 ). 
Table 1: Mineral element in leaf, stem and root samples of Garcinia manni

\begin{tabular}{|l|l|l|l|}
\hline Mineral elements (mg/100g) & Leaf & Stem & Root \\
\hline Calcium & $5.67 \pm 0.23$ & $3.77 \pm 0.40$ & $7.54 \pm 0.62$ \\
Magnesium & $3.84 \pm 0.41$ & $2.89 \pm 0.36$ & $2.67 \pm 0.33$ \\
Sodium & $4.60 \pm 0.21$ & $3.54 \pm 0.77$ & $5.74 \pm 0.42$ \\
Potassium & $6.47 \pm 0.10$ & $4.77 \pm 0.21$ & $5.29 \pm 0.42$ \\
Phosphorus & $0.45 \pm 0.02$ & $0.27 \pm 0.06$ & $0.31 \pm 0.04$ \\
Nitrogen & $3.47 \pm 0.16$ & $2.19 \pm 0.24$ & $2.42 \pm 0.20$ \\
Iron & $0.22 \pm 0.04$ & $0.17 \pm 0.06$ & $0.25 \pm 0.03$ \\
Manganese & $0.03 \pm 0.01$ & $0.03 \pm 0.02$ & $0.01 \pm 0.01$ \\
Zinc & $0.44 \pm 0.07$ & $0.29 \pm 0.05$ & $0.35 \pm 0.02$ \\
Lead & $-0.002 \pm 0.00$ & $-0.000 \pm 0.00$ & $-0.00 \pm 0.00$ \\
Copper & $0.015 \pm 0.01$ & $0.012 \pm 0.01$ & $0.010 \pm 0.01$ \\
\hline
\end{tabular}

Mean \pm standard error from 3 replicates

Table 2: Proximate contents in leaf, stem and root samples of Garcinia manni

\begin{tabular}{|l|l|l|l|}
\hline Proximate content $\mathbf{( \% )}$ & Leaf & Stem & Root \\
\hline Moisture content & $6.72 \pm 0.20$ & $4.92 \pm 0.49$ & $5.47 \pm 0.64$ \\
Ash & $2.21 \pm 0.42$ & $1.86 \pm 0.21$ & $3.30 \pm 023$ \\
Crude Protein & $6.87 \pm 0.33$ & $3.54 \pm 0.64$ & $3.40 \pm 0.49$ \\
Crude fibre & $2.86 \pm 0.49$ & $2.57 \pm 0.20$ & $2.91 \pm 0.28$ \\
Dry matter & $93.36 \pm 0.70$ & $95.06 \pm 0.38$ & $94.54 \pm 0.42$ \\
Carbohydrates & $87.26 \pm 0.56$ & $91.72 \pm 0.45$ & $90.21 \pm 0.17$ \\
\hline
\end{tabular}

Mean \pm standard error from 3 replicates

Table 3: Phytochemical contents in leaf, stem and root samples of Garcinia manni

\begin{tabular}{|l|l|l|l|}
\hline Phytochemical content (\%) & Leaf & Stem & Root \\
\hline Alkaloid & $3.20 \pm 0.14$ & $2.29 \pm 0.40$ & $2.33 \pm 0.36$ \\
Tannin & $11.87 \pm 0.21$ & $9.72 \pm 0.53$ & $5.46 \pm 0.47$ \\
Flavonoid & $0.26 \pm 0.06$ & $0.38 \pm 0.02$ & $0.42 \pm 0.06$ \\
Saponin & $2.02 \pm 0.17$ & $1.86 \pm 0.70$ & $0.36 \pm 0.03$ \\
Glycoside & $0.78 \pm 0.06$ & $0.83 \pm 0.07$ & $2.59 \pm 0.21$ \\
Phytate & $0.036 \pm 0.02$ & $0.030 \pm 0.01$ & $0.022 \pm 0.01$ \\
Oxalate & $0.06 \pm 0.01$ & $0.03 \pm 0.02$ & $0.04 \pm 0.01$ \\
Cyanide & $0.001 \pm 0.00$ & $0.002 \pm 0.00$ & $0.004 \pm 0.00$ \\
\hline
\end{tabular}

Mean \pm standard error from 3 replicates

\subsection{Discussion}

The result of mineral element composition clearly showed that there were marked variations in magnesium, potassium, phosphorus, nitrogen, calcium, sodium, zinc, iron and copper contents in leaf, stem and root of Garcinia manni. Similarly, the moisture, crude protein, dry matter, ash, crude fibre carbohydrate and crude lipid contents varied considerably in the leaf, stem and root of the test plant. This result agrees with the work of Mingzhu et al., 2015 that nutrient allocation and stoichiometric traits, together with water relations are fundamental features of shrubs. The pattern of nutrient concentrations in plant species have been reported to vary with geography and 
climate (Mingzhu et al., 2015, Etukudo and Osim, 2018). Nutrient distribution in leaves, stem and root is a function of the plant ability to obtain, transport and store nutrients (Lambers et al., 1998, Etukudo et al., 2015). Although, the leaves are the organs for production of plant food, the stems and roots apart from being the structural components of plants are the involved in uptake, transport accumulation, and storage of nutrients for plant biosynthesis (Chapin et al., 1990). Significant differences in contents of nutrient elements among leaves, stems and roots of Reaumuria soongorica were reported to be influenced by geography, climate and edaphic factors (Mingzhi, et al., 2015). This shows that the relative amount of biomass found in the various organs of plants is not fixed but may vary over time, across environments and among species (Nikias, 1994, Reich, 2002). According to Pooter et al. (2012) plant root receives more biomass if the limiting factors for growth such as water and nutrients are below ground while the shoot receives more biomass if the limiting factors such as light and $\mathrm{Co}_{2}$ are above ground.

The results of the phytochemical analysis of Garcinia manni revealed that the leaf, stem and root contained varied amounts of alkaloids, tannins, flavonoids, saponins, and glycosides, phytates, oxalates and cyanides. Similar results have been reported by various researches that medicinal plants contain bioactive compounds with different effects [Egwaikhide et al., 2008, Sofowora, 1993]. In addition, variations in distribution of phytochemicals among the leaf stem and root organs of plant have been reported (Ogwuche et al., 2014, Dikioye et al., 2017, Etukudo and Osim, 2018). The importance of alkaloids has been reported (Akinpelu et al., 2006) and is associated in the treatment of intestinal infections [Mcdevitt et al., 1996; Parekh et al., 2007]. Tannins have been implicated in the treatment inflamed tissues (Parekh et al., 2007, Musa, et al., 2009) and posses astringent properties [Igboko, 1983]. Studies on saponin revealed its medicinal value in the treatment of hyperglycaemia and human cancer [Olaleye et al., 2007, Hodek et al., 2002]. Flavonoids have been reported to exhibit antimicrobial, anti-inflammatory and antioxidant properties (Das et al., 1989).

\section{Conclusions and Recommendations}

The variations in the distribution of nutrients and phytochemicals among the leaf, stem and root of $G$. manni clearly reveal the specific organs for use in nutritional and pharmaceutical purposes. This study suggests that the test plant parts could be used as valuable material for the production of pharmaceutical drugs. In addition, the lower contents of anti-nutrients in the stem attest to its utilization as chewing stick.

\section{Acknowledgements}

We wish to appreciate the contributions from Mr. Sunday Okpata, Department of Biology, and Mr Awolabi Akeem, Department of Biochemistry, Faculty of Science, Federal University Otuoke, Bayelsa State, Nigeria.

\section{References}

[1] Etukudo, M.M. and Osim, S.E. Assesment of Mineral, Proximate and Phytochemical Composition of Leaf, Stem and Root of Maesobotrya Barteri (Baill) From Secondary Forest In Akwa Ibom State. International Journal of Advance Research, 6(1), 2018 500- 505. 
[2] Abdillahi H.S., Stafford G.I., Finnie J.F and Staden J.V. Ethnobotany, Phytochemistry and Pharmacology of Podocarpus sensus Latissimo (S.I). South African Journal of Botany, 76 (1), 2010, 1-24.

[3] Inbathamizh L. and Dr. E. Padmini. Effect of geographical properties on the Phytochemical Composition and Antioxidant Potential of Moringa oleifera Flowers. BioMedRx, 2013, 1(3), 2013, 239-247.

[4] Okeke, C.U. and Nwachukwu, A.C. Phytochemical and Proximate Analyses of Euphorbia heterophylla Linn. (Euphorbiaceae). Nigerian Journal of Botany, 22(1), 2009, 215-222.

[5] Garboui S.S., Borg-Karlson A.K and Palsson K. Tick Repellent Properties of Three Libyan Plants. Journ. Med. Entomol., 46 (6), 2009, 1415- 1419.

[6] Atangwho, I.J., Ebong, P.E., Eyong, E.U., William, I.O., Eteng, M.U., and Egbung, G.E. Comparative Chemical Composition of Leaves Some Antidiabetic Medicinal Plants: Azadirachta indica,Vernonia amygdalina and Gongronema latifolium. African Journal of Biotechnology, 8(18), 2009, 4685-4689.

[7] Nascimento, G. F., Locatelli, J., Freitas, P. C. and Silvia, G. L. (2000). Antibacterial Activity of Plant Extracts and Phytochemicals on Antibiotic Resistant Bacteria. Brazilian Journal of Microbiology, 31, 2000, 247-256.

[8] Oboh, F.O.J and Masodje, A.I. Nutritional and Antimicrobial Properties of Jatropha tanyorensis Leaves. American Journal of Science and Research, 4 (1), 2009, 7-10.

[9] Okwu, D.E. and Ekeke, O. Phytochemical Screening and Mineral Composition of Chewing Sticks in South Eastern Nigeria. Global Journal of Pure Applied Sciences, 9, 2003, 235-238.

[10] Selma M.V., Martinez-Sanchez A., Allende, A., Ros, M., Herandez, M.T., and Gil, M.I. Impact of Organic Soil Amendments on Phytochemicals and Microbial Quality of Rocket Leaves (Eruca sativa). Journal of Agriculture and Food Chemistry, 58(14), 2010, 8331-8337.

[11] Akande, J.A. and Hayashi, Y. Potency of Extract Contents from Selected Tropical Chewing Sticks against Staphylococcus aureus and Staphylococcus auricularis. World Journal of Microbiology and Biotechnology, 14, 1998, 235-238.

[12] Akande T.A., Ajao, A.T. Chemotherapeutic Values of Four Nigerian Chewing Sticks on Bacteria Isolates of Dental Infection. Global Journal of Science Frontier Research, 11(8), 2011, 90-95.

[13] Rotimi, V.O. and Mosadomi, H.A. The Effect of Crude Extracts of Nine African Chewing Sticks on Oral Anaerobes. Journal of Medical Microbiology. 23, 1987, 55-60.

[14] Anyang S. Statistical Year Book of Akwa Ibom State of Nigeria. 2013 Edn. Directorate of Statistics, Ministry of Economic Development Uyo, 2013.

[15] Wokocha, R.C.and Nneke, N.. Cassava Anthracnose disease and varietal screening for resistance in Akwa Ibom State of Nigeria. Journ. Agric. Sci. Tech., B 1, 2011, 889-895.

[16] A.O.A.C., Association of Official Analytical Chemist. Methods of analysis (16h Edition), Washington DC., U.S.A., 1999.

[17] [17.] Hack, B., Analytical Method of Determination of Mineral Nutrients. In: Dolphin and John, (Eds.). Text on Analytical in Practice, NewYork, Incorp. Press Ltd. 2000.

[18] Bohn, B.A. and Kocipai-Abyazan, R. Flavonoids and Condensed Tannins from the Leaves of Hawaiian Vaccinium vaticulatum and V. calycinum. Pacific Science, 48, 1994, 458-63.

[19] Harbone, Z.B. Phytochemical Methods: A Guide to Modern Techniques of Plant Analysis, Chapman and Hall, London, 1973, 113 - 185.

[20] Obadoni, B.O. and Ochuko, P.O. Phytochemical Studies and Comparative Efficiency of the Extracts of some Homoeostatic Plants in Edo and Delta States of Nigeria. Global Journal of Pure and Applied Sciences, 2001, 8: 203-208.

[21] Pearson, D. Chemical analysis of foods. (7th Ed), Henry Edward company, Churchchill, Livingstone, London, 1976, 218- 336. 
[22] Ikediobi, C.O., Onyia, G.O.C., and Eluwah, E.C., A Rapid and Inexpensive Enzymatic Assay for Total Cyanide in Cassava and Cassava Products. Agric. Biol. Chem. 44 (12), 1980, 2803-09.

[23] Olugboji, O.O., Biochemical Studies on the Cyanide Content of Malted sorghum (Sorghum bicolor L. Moench) and sorghum Products and the Fate of sorghum dhurrin in the rat. M. Sc Thesis, Ahmadu Bello University,Zaria, Nigeria, 1987.

[24] Oberlease, D. (1962). Phytates. F. Strong (Ed.), Toxicants Occurring Naturally in Foods. Washington D.C, National Academy of Sciences, 1962, 363-71.

[25] Obi, 1.U. Statistical Methods of Detecting Differences between Treatment Means and Research Methodology Issues in Laboratory and Field Experiments. Nigeria, AP Express publishers limited, 2002.

[26] Mingzhu H., Ke Zhang, Huijuan Tan, Rui Hu, Jieqiong Su, Jin Wang, Lei Huang, Yafeng Zhang and Xinrong Li. Nutrient Levels within Leaves, Stems, and Roots of the Xeric Species Reaumuria oongorica in Relation to Geographical, Climatic, and Soil Conditions. Ecology and Evolution, 5(7), 2015, 1494-1503.

[27] Lambers, H., Chapin, F.S. and Pons, T.L. Plant Physiological Ecology. New York, NY: Springer; 1998.

[28] Etukudo, M.M., Hamilton-Amachree, A., and Roberts, E.M.I. Eco-physiological Studies of Elemental and Proximate Contents of Gnetum africanum Welw and Telfairia occidentalis Hook seeds from two Ecological Zones of Akwa Ibom State. European International Journal of Science and Technology. 4(6), 2015, 47-53.

[29] Chapin, F.S, Schulze, E.D. and Mooney, H.A. The Ecology and Economics of Storage in Plants. Annu. Rev. Ecol. Syst. 21, 1990, 423-447.

[30] Niklas, K.J. Plant Allometry. The Scaling of Form and Process. Chicago, IL, USA: The University of Chicago Press, 1994.

[31] Reich, P. Root-shoot Relations: Optimality in Acclimation and Adaptation or the "Emperor's new clothes"? In: Waisel Y, Eshel A, Kafkafi U, eds. Plant Roots, the Hidden half, 3rd edn. New York, NY, USA: Marcel Dekker, 2002, 205-220.

[32] Pooter, H., Niklas, K. J., Reich, P. B., Oleksyn, J. Poot, P. Karl, Biomass Allocation to Leaves, Stems and Roots: Meta-analyses of Interspecific Variation and Environmental Control, 193(1), 2012, 30-50.

[33] Egwaikhide, P.A., Okeniyi, S.O., Akporhonor, E.E. and Erua, S.O. (2008). Studies on Bioactive Metabolite Constituents and Antimicrobial Evaluation of Leaf Extracts of Eucalyptus globulus. Agricultural Journal. 3(1), 2008, 42-45.

[34] Sofowara, A. (1993). Medicinal Plants and Traditional Medicine in Africa. 2nd edition John Wiley and Son Ltd. 1993, 150-153.

[35] Ogwuche, C.E, Amupitan, J.O, Ndukwe, I.G, and Ayo, R.G. Isolation and Biological Activity of the Triterpene B- Amyrin from the Aerial Plant Parts of Maesobotrya barteri. Med. Chem... 4(11), 2014, 729- 733.

[36] Dikioye, Emmanuel P., Emmanuel Onyebuchi E., Uche Chinedu N., Ikehide F.and Matthew Owhonda W. Phytochemical Composition and Analgesic Property of Ethanolic Leaf Extract of Maesobotrya barteri. Journ. Advan. Bio. Biotech. 13(4), 2017, 1-8.

[37] Akinpelu, D.A. and Onakoya, T.M. Antimicrobial Activities of Medicinal Plants used in Folklore Remedies in South-West. African Journal of Biotechnology. 5, 2006, 1078-1081.

[38] McDevitt, J.Y, Schneider, D.M, Katiyar, S.K. and Edhnd, T.D. Berberine a candidate for the treatment of diarrhea in AIDS patients, abstract 175. In Program and Abstracts of the 36th Interscience Conference on Antimicrobial Agents and Chemotherapy, American Society for Microbiology, Washington, D. C, 1996.

[39] Parekh, M., and Chanda, K. In Vitro Antibacterial Activity of Crude Methanol Extracts of Woodfordia fruticosa Kurz flower a (Lythaceae). Brazillian Journals of Microbiology 38, 2007, 2. 
[40] Musa A. M., Aliyu A. B, Yaro A. H., Magaji M. G., Hassan H. S. and Abdullahi M. I. Preliminary Phytochemical, Analgesic and Anti-inflammatory Studies of the Methanol Extracts of Anisopusmannii (N.E. Br) (Asclepiadaceae) in Rodents. African Journal of Pharmacy and Pharmacology, 3(8), 2009, 374-378

[41] Igboko, D.O. Phytochemical Studies on Garcinia kola Heckel. MSc Thessis. University of Nigeria Nsukka., 1983, 202.

[42] Olaleye, M.T. Cytotoxicity and Antibacterial Activity of Methanolic Extracts of Hibiscus sabdariffa. J. Med. Plants Res. 1(1), 2007, 9-13.

[43] Hodek, P., Trefil, P., Stilborova, M. Flavonoids - potent and versatile biologically active compounds interacting with cytochrome P450.Chemico-Biol. Intern. 139(1), 2002, 1-21.

[44] Das, P.C., Das, A. and Mandal, S. (1989). Antimicrobial and anti-inflammatory activities of the seed kernel of Mangiferaindica. Fitoterapia, 60: 235-240.

\footnotetext{
*Corresponding author.

E-mail address: mbosombosowo@ yahoo.com
} 